\title{
Chromosome numbers of some species of Pteris (Pteridaceae) in Java, Indonesia
}

\author{
TITIEN NGATINEM PRAPTOSUWIRYO ${ }^{1, \boldsymbol{v}}$, MUGI MUMPUNI ${ }^{2}$ \\ ${ }^{1}$ Center for Plant Conservation-Bogor Botanical Gardens, Indonesian Institute of Sciences. Jl. Ir. H. Juanda No. 13, P.O. Box 309, Bogor 16003, West \\ Java, Indonesia. Tel. +62-251-8322187. Fax.+62-251-8322187, `email: tienpferns@gmail.com; tienpferns@yahoo.com \\ ${ }^{2}$ Faculty of Biology, Universitas Medan Area. Jl. Kolam No. 1 Medan Estate, Medan 20223, North Sumatra, Indonesia
}

Manuscript received: 19 September 2018. Revision accepted: 26 October 2018.

\begin{abstract}
Praptosuwiryo TNg, Mumpuni M. 2018. Chromosome numbers of some species of Pteris (Pteridaceae) in Java, Indonesia. Biodiversitas 19: 2118-2126. Pteris L. (Pteridaceae) is a large fern genus consisting of about 250 species which distributed predominantly in tropical and subtropical countries. The genus grows in a diversity of ecosystems, either terrestrially or lithophytically, although most species occur in the forest. A study of the cytology of Pteris in Java is being undertaken for the conceptual understanding of the interrelationships between various fern species in the Malesian region. This aims of our study are: (1) to observe somatic chromosome number of some species of Pteris in Java; (2) to determine the reproduction types of the observed species by counting the spore number per sporangium; (3) to discuss polyploidy in the species in relation to plant morphological variation across their geographical distribution. Chromosome counts for eight species are reported. Pteris biaurita is an apogamous diploid species $(2 \mathrm{n}=58)$. Pteris ensiformis var. ensiformis has chromosome numbers of $2 \mathrm{n}=87$ (apogamous triploid) and $2 \mathrm{n}=116$ (sexual tetraploid), while $P$. ensiformis var. victoriae has a chromosome number $2 \mathrm{n}=58$ and is a sexual diploid. Pteris fauriei is an apogamous triploid species $(2 \mathrm{n}=87)$. Pteris longipinnula has a chromosome number of $2 \mathrm{n}=116$ (tetraploid). Pteris multifida and $P$. vittata are sexual tetraploids $(2 \mathrm{n}=116)$. Pteris tripartita has two ploidy levels (sexual diploid and tetraploid). Another currently unplaced Javanese Pteris $\mathrm{sp}$. has $2 \mathrm{n}=$ 87 (apogamous triploid). Diploid P. biaurita, tetraploid P. ensiformis, triploid P. fauriei, diploid $P$. tripartita, and teraploid $P$. vittata are new record cytotypes for Central Java. Polyploidy in the genus in relation to plant morphological variation across its geographical range is discussed.
\end{abstract}

Keywords: Chromosome, Java, Pteris

\section{INTRODUCTION}

Chromosome number is the most basic feature concerning the genome of a species (Peruzzi et al. 2012). Analyses of chromosome numbers are very important as they represent a fundamental step in the study of any group of organisms. Chromosome counts provide indispensable information on genetic discontinuities within and among species, and they contribute for the understanding of phylogenetic relationships at all taxonomic levels (Windham and Yatskievych 2003). Cytological studies have resolved various taxonomic problems and have revealed details of evolutionary patterns and speciation processes in Pteridophytes (Lovis 1977). Because it is considered that ferns have been developed in evolution by hybridization and doubling (Wagner 1954).

As pointed out by Ivanova \& Pie, kos-Mirkowa (2003) polyploidy seems to be the most important processes among the processes that have played significant roles in pteridophyte differentiation and speciation in ferns. Cytological and cytogenetic investigations have revealed that polyploidy is very common in Pteridophyta. It was estimated that polyploidy in ferns as high as $95 \%$ (Walker 1979; Grant 1981). The majority of polyploid ferns appear to be allopolyploids, and the success of polyploidy seems closely associated with hybridization (Bir 1988, Cubas 1989).

Pteris is a fairly large fern genus which consisting of about 250 species (Holttum 1954; Tryon et al. 1990). Morphologically, Pteris species are recognized by their marginal sori supported by a collecting vein and protected by an indusium formed by the reflexed lamina margin, and by trilete spores which are usually with an equatorial cingulum (Holttum 1954; Martínez 2016). Pteris contains herbaceous perennials with short-creeping to erect, usually compact rhizomes, stalked fronds with laminae divided into a simply pinnate to bipinnate arrangement, or sometimes tripartite, usually with the basal pinnae bearing an enlarged basiscopic pinnule (Holttum 1966; Prado and Windisch 2000; Martínez 2011). It is a cosmopolitan fern genus which distributed in temperate, subtropical, and tropical regions of the world, extending to the south in China, New Zealand, and Tasmania, west to South Africa, north to Korea and Japan, across the United States, as well as the Mediterranean region of Europe (Copeland 1947; Tryon and Tryon 1982). This genus grows either terrestrially or lithophytically (on rocks) on a diverse ecology although most species occur in forest, frequently secondary forests in opening or along rocky stream banks, coastal areas and xeric niches (Copeland 1947; Chao et al. 2014). 
Many species of Pteris have several ploidy levels (Walker 1966; Wang 1989; Praptosuwiryo 2003; Praptosuwiryo and Darnaedi 2008; Chao et al. 2012a, 2012b; Jaruwattanaphan et al. 2013; Nakato and Ebihara 2016) and are found in several geographical areas, such as P. cretica and P. vittata (Manton 1950; Khare and Kaur 1983; Wang 1989) which likely reflect the ecological differentiation within species. The first extensive cytological study of the genus Pteris was carried out by Walker (1966). This study included 82 species and reported that the base number of chromosomes in Pteris is 29. Recently data on the cytological of 106 Pteris species were reviewed by Chao et al. (2012b). It is presumed that about $60 \%$ of Pteris species are polyploids, including triploids, tetraploids, pentaploids, hexaploids, and octoploids (Walker 1956, Kuriachan and Ninan 1976; Wang 1989; Chao et al. 2012b).

It is estimated that Sout East Asia has about 80 species of Pteris (Schneider and Rusea 2003). Malesian region has more than 40 species of Pteris. In Java, Backer and Posthumus (1939) recorded 19 species of Pteris. Praptosuwiryo (2013) reported two new species record of Pteris for Java, namely $P$. insignis and $P$. walichiana, from Mount Slamet. Nevertheless recently reports on the cytological study of this genus in Malesian region are only a few. The first cytological record on Pteris of Jawa was reported by Walker (1962), viz. diploid type of P. biaurita, but he did not mention the specific locality of the voucher specimen. Darnaedi (1992) reported three species from Gede-Pangrango National Park, West Java, namely: P. biaurita, P. pellucida, and P. longipinnula. Zubaidah (1998) studied cytology of $P$. biaurita in East Java. Praptosuwiryo (2003) reported one species from Lombok Island, $P$. venulosa $\mathrm{Bl} .(2 \mathrm{n}=3 \mathrm{x})$. Praptosuwiryo and Darnaedi (2008) reported chromosomes account on six wild species of Pteris from Bogor Botanic Gardens, viz.: P. biaurita $(2 \mathrm{n}=58)$, . ensiformis $(2 \mathrm{n}=116), P$. fauriei $(2 \mathrm{n}=87), P$. multifida $(2 \mathrm{n}=116)$, P. tripartita $(2 \mathrm{n}=58$ and $2 \mathrm{n}=116)$, and $P$. vittata $(2 \mathrm{n}=116)$. Hastuti et al. (2011) reported two ploidy level of P. multifida, apogamous triploid $(2 n=3 x)$ and sexual tetraploid $(2 n=4 x)$. Mumpuni et al. (2015) studied on the intraspecific polyploid of $P$. vittata from Java and found apogamous pentaploid $(2 \mathrm{n}=5 \mathrm{x})$ and sexual tetraploid $(2 \mathrm{n}=4 \mathrm{x})$. Efendi et al. (2014) reported chromosome account of Pteris ensiformis var. victoriae $(2 \mathrm{n}=58$ and $2 \mathrm{n}=87)$ and var. ensiformis $(2 \mathrm{n}=116)$.

Here we continue cytological study on Pteris of the Malesian fern flora by choosing some species of Pteris and collecting plants material from some localities of Java. This study contributes to the interrelationships concepts of the various fern species in Malesian region, especially to support data that may be helpful to phylogenetic studies of the genus Pteris. The aims of this study are: (i) to observe somatic chromosome number of some species of Pteris in Java; (ii) to determine the reproduction types of the observed species by counting the spore number per sporangium; (iii) to discuss polyploidy in the species in relation to plant morphological variation across their geographical distribution.

\section{MATERIALS AND METHODS}

\section{Plant specimen}

A number of living plants specimen for the cytological studies were collected from the natural population of some locations in Java (Table 1.). Collected specimens were identified by consulting Backer and Posthumus 1939, Holttum (1966), and Edie (1978). Voucher specimens were deposited at BOHB (Herbarium of Bogor Botanical Gardens).

\section{Chromosome observation}

Preparation of chromosome samples was carried out by using squash method as this method can be used as an alternative to ensure good physical separation of chromosomes (Fukui 1996). The preparation procedure followed the procedures developed by Manton (1950) and modified by Praptosuwiryo and Darnaedi (2008). Root tips were pretreatment in $0.002 \mathrm{M}$ 8-hydroxyquinoline solution for 24 hours at $3-4^{\circ} \mathrm{C}$. They were fixed in $45 \%$ acetic acid for 10 minutes and macerated in a mixture of $\mathrm{CH} 3 \mathrm{COOH}$ $45 \%$ : I N HCl $=1: 3$ at $60^{\circ} \mathrm{C}$ for 3-4 minutes. The fixed roots were stained and squashed in aceto-orcein solution. Chromosome observation was carried out under the microscope by using 1000x magnification. $\square$

\section{Reproduction types observation}

Reproduction mode was determined by spore counting for each sporangium by following procedures described by Manton (1950), Knobloch (1966), Lovis 1977 and Walker $(1979,1984)$. Each individual plant was taken $10-15$ spores for counting under a binocular microscope. The spore number was recorded as "64 s/s" if approximately 64 spores each were counted at least in two sporangia, and as ' $32 \mathrm{~s} / \mathrm{s}$ ' if approximately 32 spores each were counted (Ebihara et al. 2014). The spores number per sporangium is related to the reproduction mode. Plants with 64 spores generally have sexual reproduction, whereas those with 32 or 16 spores usually have apogamous reproduction (Knobloch 1966; Walker 1984).

\section{RESULTS AND DISCUSSION}

New data on chromosome numbers and reproduction types of eight species of 33 individuals plants collected from five localities in Java are reported (Table 1 and Figure 1.). There is only one ploidy level on P. biaurita, apogamous diploid. Pteris ensiformis var ensiformis shows the chromosome number of $2 \mathrm{n}=87$ (apogamous triploid) and $2 \mathrm{n}=116$ (sexual tetraploid), while $P$. ensiformis var. victoria reveals $2 \mathrm{n}=58$ (sexual diploid). Pteris fauriei is apogamous triploid $(2 \mathrm{n}=87)$. Pteris longipinnula shows chromosome number $2 \mathrm{n}=116$ (tetraploid). Pteris multifida and $P$. vittata are sexual tetraploids $(2 \mathrm{n}=116)$. Pteris tripartita has two ploidy level (sexual diploid and tetraploid). Pteris sp. has $2 \mathrm{n}=87$ (apogamous triploid). New record cytotypes of Pteris for Central Java are reported, viz. diploid $P$. biaurita, tetraploid $P$. ensiformis, triploid $P$. fauriei, diploid $P$. tripartita and teraploid $P$. vittata. Discussion for each species is presented. 
Table 1. Chromosome Number and Reproduction Types of Pteris in Java, Indonesia

\begin{tabular}{|c|c|c|c|c|}
\hline Species & Voucher & $\begin{array}{l}\text { Chromosome } \\
\text { number (2n)/ } \\
\text { ploidy level }\end{array}$ & $\begin{array}{l}\text { Types of } \\
\text { reproduction }\end{array}$ & Locality \\
\hline \multirow[t]{6}{*}{ Pteris biaurita $\mathrm{L}$. } & TNgP 3219 & 58/diploid & - & $\begin{array}{l}\text { Petak 41a, Northern Slope of Mt. Slamet, Desa Karang } \\
\text { Mangu, Kec. Pulosari, Kab. Pemalang (RPH Karang } \\
\text { Sari, BKPH Moga, KPH Pekalongan Barat). } 1300 \mathrm{~m} \\
\text { asl., Central Java. }\end{array}$ \\
\hline & MM 144 & 58/diploid & Apogamous & Bogor Botanical Gardens, West Java. Ca. 250 m asl. \\
\hline & TNgP \& YF 25 & 58/diploid & Apogamous & ibid. \\
\hline & TNgP \& YF 17 & 58/diploid & Apogamous & Ibid. \\
\hline & TNgP \& NI 03 & 58/diploid & Apogamous & $\begin{array}{l}\text { Among Acalypa siamensis, Ngadirejo country, } \\
\text { Mojosongo sub-district, Boyolali District, Central Java. } \\
\text { Ca. } 295 \mathrm{~m} \text { asl. }\end{array}$ \\
\hline & TNgP \& NI 06 & 58/diploid & Apogamous & $\begin{array}{l}\text { Near ravine and bridge, between Masahan-Wates } \\
\text { Country, Mojosongo Sub-district, Boyolali District, } \\
\text { Central Java. Ca. } 300 \mathrm{~m} \text { asl. }\end{array}$ \\
\hline \multirow[t]{6}{*}{ P. fauriei Hieron } & MM 156 & 87/triploid & Apogamous & Bogor Botanical Gardens, West Java. Ca. $250 \mathrm{~m}$ asl. \\
\hline & TNgP \& YF 11 & 87/triploid & Apogamous & Ibid. \\
\hline & TNgP \& NI 05 & $87 /$ triploid & Apogamous & $\begin{array}{l}\text { Near ravine and bridge, between Masahan-Wates } \\
\text { Country, Mojosongo Sub-district, Boyolali District, } \\
\text { Central Java. Ca. } 300 \mathrm{~m} \text { asl. }\end{array}$ \\
\hline & TNgP \& NI 07 & 87/triploid & Apogamous & ibid. \\
\hline & TNgP \& NI 08 & 87/triploid & Apogamous & Ibid. \\
\hline & TNgP \& NI 10 & 87/triploid & Apogamous & Ibid. \\
\hline \multirow{6}{*}{$\begin{array}{l}\text { P. ensiformis var. } \\
\text { ensiformis Burm. } \mathrm{f} \text {. }\end{array}$} & $\mathrm{TNgP} 2719 \mathrm{c}$ & 87/triploid & Apogamous & Bringin, Semarang, Central Java. \\
\hline & TNgP 2719 & 116/tetraploid & - & Ibid. \\
\hline & DD s.n. 1 May 2000 & 116/tetraploid & - & Bogor, West Java. \\
\hline & MM 157 & 116/tetraploid & Sexual & Bogor Botanical Gardens, West Java. Ca. $250 \mathrm{~m}$ asl. \\
\hline & MM 152 & 116/tetraploid & - & Ibid. \\
\hline & $\mathrm{TNgP} \& \mathrm{NI} 08$ & 116/tetraploid & - & $\begin{array}{l}\text { Near ravine and bridge, between Masahan-Wates } \\
\text { Country, Mojosongo Sub-district, Boyolali District, } \\
\text { Central Java. Ca. } 300 \mathrm{~m} \text { asl. }\end{array}$ \\
\hline $\begin{array}{l}\text { P. ensiformis var. } \\
\text { victoriae Baker }\end{array}$ & TNgP s.n. & 58/diploid & Sexual & Bogor, West Java. \\
\hline \multirow[t]{2}{*}{$\begin{array}{l}\text { P. longipinnula Wall. } \\
\text { ex J. Agardh }\end{array}$} & MM 161 & 116/tetraploid & - & $\begin{array}{l}\text { Cibodas Botanical Gardens, West Java. Ca. } 1270 \text { m } \\
\text { asl. }\end{array}$ \\
\hline & MM 163 & 116/tetraploid & - & Ibid. \\
\hline P. multifida Poir. & MM 145 & 116/tetraploid & Sexual & Paledang, Bogor, West Java. $250 \mathrm{~m}$ asl. \\
\hline \multirow[t]{8}{*}{ P. tripartita Sw. } & MM 158 & 58/diploid & Sexual & Bogor Botanical Gardens, West Java. Ca. $250 \mathrm{~m}$ asl. \\
\hline & MM 142 & 116/tetraploid & - & ibid. \\
\hline & MM 148 & 116/tetraploid & - & Ibid. \\
\hline & TNgP \& YF 04 & 58/diploid & Sexual & Bogor Botanical Gardens, West Java . Ca. $250 \mathrm{~m}$ asl. \\
\hline & TNgP \& YF 26 & 58/diploid & Sexual & ibid. \\
\hline & $\begin{array}{l}\text { TNgP s.n. }(20 \text { Feb. } \\
2015)\end{array}$ & 58/diploid & Sexual & Ibid. \\
\hline & $\begin{array}{l}\text { TNgP s.n. (13 Arpil } \\
\text { 2015) }\end{array}$ & 58/diploid & Sexual & Bogor Botanical Gardens, West Java. \\
\hline & TNgP \& NI 04 & 58/diploid & - & $\begin{array}{l}\text { Among Acalypa siamensis plants, } \\
\text { Ngadirejo country, Mojosongo sub-district, Boyolali } \\
\text { District, Central Java. Ca. } 295 \mathrm{~m} \text { asl. }\end{array}$ \\
\hline \multirow[t]{2}{*}{ P. vittata $\mathrm{L}$. } & MM 149 & 116/tetraploid & Sexual & Paledang, Bogor, West Java Province. Ca. 250 m asl. \\
\hline & $\mathrm{TNgP} \& \mathrm{NI} 02$ & 116/tetraploid & Sexual & $\begin{array}{l}\text { Ngadirejo Country, Mojosongo Sub-district, Boyolali } \\
\text { District, Central Java. Ca. } 285 \mathrm{~m} \text { asl. }\end{array}$ \\
\hline Pteris sp. & MM 185 & 87/triploid & Apogamous & Curug Nangka, Bogor, West Java. \\
\hline
\end{tabular}




\section{Pteris biaurita L.}

Pteris biaurita is regarded as a pantropic species and occurs both in lowland and mountains, in moist places. It is differentiated from other species of Pteris by characters as follows: Basal pinnae branched but not longer than the others; the lamina on the basiscopic side of the midrib of a pinna is nearly wider than that on the acroscopic side; veins forming a regular series of narrow areoles on the side of the costa (Holttum 1966). The thin leaf brake fern P. biaurita L. in Java usually is found in semi opened and or shady places with humid condition on humus-rich soil as well as on semi-sandy soil (Backer and Posthumus 1939).

The beginning chromosome account of $P$. biaurita was reported by Walker (in Manton and Sledge 1954), Abraham et al. (1962), Walker $(1962,1966)$ and Roy and Sakya (in Fabbri 1963). They found the diploid type of $P$. biaurita. Apogamous diploid of $P$. biaurita was first reported from Jamaica (1966). Praptosuwiryo and Darnaedi (2008) reported apogamous diploid of $P$. biaurita growing spontaneously in the Bogor Botanic Gardens in moist and fairly shady place.

In the present study, two individuals of P. biaurita from West Java (MM 144 ) and Central Java were found to be a diploid apogamous with 32 spores per sporangium. Punetha and Sen (1989) reported P. biaurita from Kumaon (northwest Himalaya) as apogamous triploid, chromosome number $\mathrm{n}=87$ with 32 spores per sporangium. In Malang, East Java, Zubaidah (1998) found apogamous diploid and apogamous tetraploid $P$. biaurita. Interestingly, we recognize three cytotypes of $P$. biaurita in its distribution area, namely apogamous diploid, apogamous triploid and apogamous tetraploid, but we have not found its sexual types, yet. Further cytotaxonomical studies are needed to unravel this species complex.

\section{Pteris ensiformis Burm. f.}

Pteris ensifromis is distributed in Ceylon and South India, North India and China, through Malesia to Australia and Polynesia (Holttum 1966). This species is conspicuously common fern in Java. In Java, this species consists of two varieties, namely $P$. ensiformis var. ensiformis and $P$. ensiformis var. victoriae. The first variety is widely distributed in Java, whereas the second variety is commonly found as ornamental cultivation and the locality of origin is not reported. The two varieties are distinguished by the coloration of the lamina. Pteris ensiformis var. ensiformis has full green color of lamina whereas $P$. ensiformis var. victoriae shows white and green coloration of lamina.

It was observed that the two varieties of $P$. ensiformis also show differences in chromosome number or ploidy level. Pteris ensiformis var. ensiformis has two ploidy levels, viz. sexual tetraploid $(2 \mathrm{n}=116)$ and apogamous triploid $(2 \mathrm{n}=87)$, whereas $P$. ensiformis var. victoriae shows only sexual diploid (Table 1.) Cytological information on $P$. ensiformis is more distributed than other species of Pteris. Brownlie (1965) recorded $n=58$ from Kalabere, New Caledonia, without information of its spore number per sporangium or reproduction type. Wang (1989) reported sexual tetraploids with $\mathrm{n}=58$ from Chine without information on its variety. Tetraploid sexual was also found in Jamaica (Walker 1966). Efendi et al. (2014) reported new cytotypes of Pteris ensiformis var. victoriae and one cytotype of var. ensiformis from Indonesia; Pteris var. victoriae with $2 \mathrm{n}=58$ (sexual diploid) was from Gorontalo, North Sulawesi, and $2 n=87$ (triploid) from Lombok Island and Bogor, West Java, and P. ensiformis var. ensiformis with $2 \mathrm{n}=116$ (sexual tetraploid).

Pteris fauriei Hieron. In comparison with the closely related species of P. fauriei, P. latipinna Y.S.Chao \& W.L.Chiou, Chao et al. (2017) described the morphological diagnostic characteristics of $P$. fauriei var. fauriei as follows. Lamina $15-40 \mathrm{~cm}$ long, $10-35 \mathrm{~cm}$ wide; length/width ratio 1.2-1.5. Lateral pinnae of sterile fronds 2-7 pairs, straight, sessile or short petiolate, lanceolate, not narrowed at base, 2-3.5 cm width; basal pinna-segments free to the rachis. Terminal pinnae are smaller than lateral pinnae. Pteris fauriei is distributed in Japan, China, the Ryukyu Islands, Taiwan and Vietnam (Shieh 1975, 1994).

Roy and Holttum (1965) reported diploid P. fauriei from Southern China. Kato et al. (1992) reported apomixes triploid of P. fauriei of Yunnan, Southwestern China. In Taiwan, two varieties of $P$. fauriei have been confirmed, and both varieties have different cryptic characteristics and prefer different niches (Chao et al. 2017). Pteris fauriei Hieron. var. fauriei, apomictic and triploid $(2 \mathrm{n}=87)$, usually has herbaceous laminae and prefers cooler sites; $P$. fauriei var. minor Hieron., sexual and diploid $(2 \mathrm{n}=58)$, usually has coriaceous laminae and is found in warmer sites (Huang et al. 2006, Huang et al. 2007). The two varieties can also be differentiated by their gametophyte characteristics. Pteris fauriei var. minor produces sporophytes by sexual mode, whereas $P$. fauriei var. fauriei produces sporophytes by apogamy (Huang et al. 2006). In Taiwan, in general, triploids are found at higher elevations than the diploids (Huang et al. 2007). Roy and Holttum (1965) stated that $P$. fauriei of China and Japan belongs to the complex of $P$. quadriaurita Ret.

\section{Pteris longipinnula Wall. Ex J. Agardh.}

The first record on chromosome account of $P$. longipinnula was reported by Walker (1962). Walker (1962) found three cytotypes of $P$. longipinnula, viz. diploid $(2 n=58)$, triploid $(2 n=87)$, and tetraploid $(2 n=$ 116). Present study only reported two individuals of tetraploid collected from Mt. Gede, Gede-Pangrango National Park, West Java. Darnaedi (1992) also reported a tetraploid type $(2 n=116)$ from Mt. Gede. Diploid and triploid type of $P$. longipinnula have not been recorded from Java.

Holttum (1966) stated that $P$. longipinnula is one of the species of the group of $P$. quadriaurita, which is so polymorphic in the tropics of both Old and New Worlds. Holttum (1966) explained that typically P. longipinnula has green stipe and rachis, broad pinnae narrowed at the base and caudate at the apex, the lobes broad, with sori almost from base to apex, the veins only once forked, the costal spines short and costular spines few. Based on specimens collected from Malay Peninsula, Holttum (1966) recognized three groups of specimens which are out of the 
typical forms: (i) with narrower pinnae, the lowest branched; (ii) with somewhat narrower pinnae which are often broadly cuneate at the base and only slightly caudate at the apex, narrower and closer lobes, the basal pinnae branched, stipe and rachis more or less flushed with purple. This group comes somewhat between $P$. longipinnula and $P$. asperula J. Sm.; (iii) Pinnae narrow (lowest 2,5-3,5 cm wide), with 10-24 pairs of veins, rather shortly caudate; veins forked well above their bases; lobes about $5 \mathrm{~mm}$ wide above the base; basal pinnae forked; old stipes and rachis a little flushed with purple. These plants are intermediate between $P$. biaurita and $P$. longipinnula. Further studies for these complex species from their geographical range should be done to unravel their status. As stated by Holttum (1966) that many specimen collections that cover all stages of development, from young to fully mature plants must be studies before we can judge their status. The morphological variation occurs owing to environmental differences should be found out to judge their status. Therefore further study on the cytotaxonomy of $P$. longipinnula and its closely related species need to be done.

\section{Pteris multifida Poir.}

The spider brake fern, $P$. multifida, is recognized by morphological characters as follow: Lamina simple pinnate; terminal pinnae linear-oblanceolate; lateral pinnae 1-4 pairs; basal pinnae 1-3 branched; upper portion of rachis winged (Edie 1978). Morphologically, P. multifida is similar to $P$. cretica. However, the differentiation between two species can be recognized by the following characteristics. The mature lower pinnae of $P$. multifida regularly show both acroscopic and basiscopic lobes. In $P$. cretica, lobes are formed on the basiscopic sides only. The decurrent part of terminal pinnae of $P$. multifida are longer and run parallel to the rachis, whereas the decurrent part of the terminal pinnae of $P$. cretica are shorter. Pteris multifida is widely distributed in China and Japan, and also widely cultivated in other countries (Roy and Holttum 1965).

Cytological observations of the spider brake fern have been carried out by several researchers, such as in South China (Roy and Holttum 1965),) Japan (Mitui 1980), Ceylon, Hongkong, Himalaya (Walker 1962), and Java (Praptosuwiryo and Darnaedi 2008). Results of these studies revealed that $P$. multifida has infraspecific variation. Three ploidal levels were found, namely diploid type (Walker 1962), triploid type (Praptosuwiryo and Darnaedi 2008), and tetraploid type (Walker 1962; Roy and Holttum 1965; Mitui 1980; Praptosuwiryo and Darnaedi, 2008).

We report only one individual cytological record for $P$. multifida, viz. MM 145 with tetraploid sexual (Fig). Recently a cytological study on P. multifida from Bogor, West Java, also showed two ploidy level, namely apogamous triploid $(2 \mathrm{n}=87)$ and sexual tetraploid $(2 \mathrm{n}=$ 116) (Hastuti et al. 2011). The two cytotypes are very hard to be differentiated morphologically, but anatomically the two cytotypes can be differentiated by their epidermal cell number. The sexual tetraploid type has a greater number of epidermal cell than those apogamous triploid type.

\section{Pteris tripartita Sw.}

Pteris tripartita, in abroad sense, is very widely distributed in the tropics of the Old World (including Africa), Australia and Polynesia (Holttum and Roy 1965, Holttum 1966). This species can be found in the lowlands and at moderate elevations on the mountains, in open ground, well-drained but moist places. P. tripartita can be recognized by diagnostic characters as follow: Frond tripartite, the middle branch deeply bipinnatifid. The lateral branches as long as the middle branch, each with large secondary bipinnatifid branch on the lower side towards the base, the lowest basal pinna on this branch usually bearing several pinnatifid leaflets on its lower side, the lamina on its upper side lobed as in the other pinnae. The texture of lamina thin, herbaceous; veins forming a series of narrow costa areoles, each the series of costa areoles continuous from one costule to the next, a series of shorter areoles on either side of the costule almost to its apex (Holttum 1966).

All plants so named hitherto examined cytologically before Holttum and Roy (1965) have been tetraploid. Now, in this study, we report two cytological types of $P$. tripartita, diploid and tetraploid. Recently finding of tetraploid plants of Jawa was reported by Praptosuwiryo and Darnaedi (2008). The first diploid of $P$. tripartita was reported by Holttum and Roy (1965) from New Guinea, East Malesia. Diploid type of $P$. tripartita from West Malesia (West Java: wild plants of Bogor Botanical Gardens) was reported by Praptosuwiryo and Darnaedi (2008). The diploid type of $P$. tripartita from New Guinea has venation typical of $P$. tripartita, but lobes of pinnae are closer together than in the lowland form of the species which is common in Malaya (Holttum and Roy 1965). However, Praptosuwiryo and Darnaedi (2008) did not find the morphological differences between the diploid and tetraploid type of $P$. tripartita in West Java. Further studies dealing with cytomorphology of $P$. tripartita in its areas distribution range are needed.

\section{Pteris vittata $\mathbf{L}$.}

Pteris vittata is very widely distributed in the tropics and subtropics of the Old World. This plant is also one of the common species in Java. In Java, it can be found from the lowlands to the higher coverage until approximately $2000 \mathrm{~m}$, in the open, sunny to the slightly shaded area, steep earth, and rock wading, on old walls, especially on limestone rocks, also occurring elsewhere, often in great numbers together (Backer and Posthumus 1939).

This species is very easy to be recognized in the field by diagnostic characters as follow: Frond simply pinnate with a terminal pinna like the lateral ones; pinnae numerous, 1-4 cm apart, middle ones longest, basal ones gradually reduced and often very short, upper ones only slightly reduced and much shorter than the terminal pinna except in larger fronds, all pinnae sessile and oblique. Veins free, nearly at right angle to the costa, usually forked near the costa. Sori continuous from near the base to near the apex of each pinna (Holttum 1966). This species is highly valued as an ornamental plant (Srivastava et al. 
2007). It has recently been reported as phytoremediator; this species can accumulate a large concentration of arsenic in its aboveground biomass (up to 23,000 mg per $\mathrm{kg}$ ) (Ma et al. 2001).

Cytological study on the ladder brake fern $P$. vittata is very interesting as this species is widely distributed in the world with multi-level habitats. Cytological study on $P$. vittata from Chine by Wang (1989) showed that this species is a species complex which includes several cytotypes. Wang (1989) reported a sexual tetraploid from south Guangdong and south Yunnan. He also added that there were a sterile triploid with the chromosome number of $n=201 \mathrm{I}+26 \mathrm{II}+5 \mathrm{III}$ and a sterile tetraploid hybrid with the chromosome number of $n=9 \mathrm{I}+45 \mathrm{II}+3 \mathrm{III}+21 \mathrm{~V}$ from south Yunnan and south Guangdong respectively. As stated by Wang (1989) the distribution pattern of different cytotypes in $P$. vittata complex may indicate that the tropics is more favorable to the formation and surviving of polyploid than the subtropics. However, Wang (1989) also stated that its natural ancestral diploid had been widely found in the subtropical regions of China, such as Sichuan, Guizhou, Yunnan and Hubei Provinces.

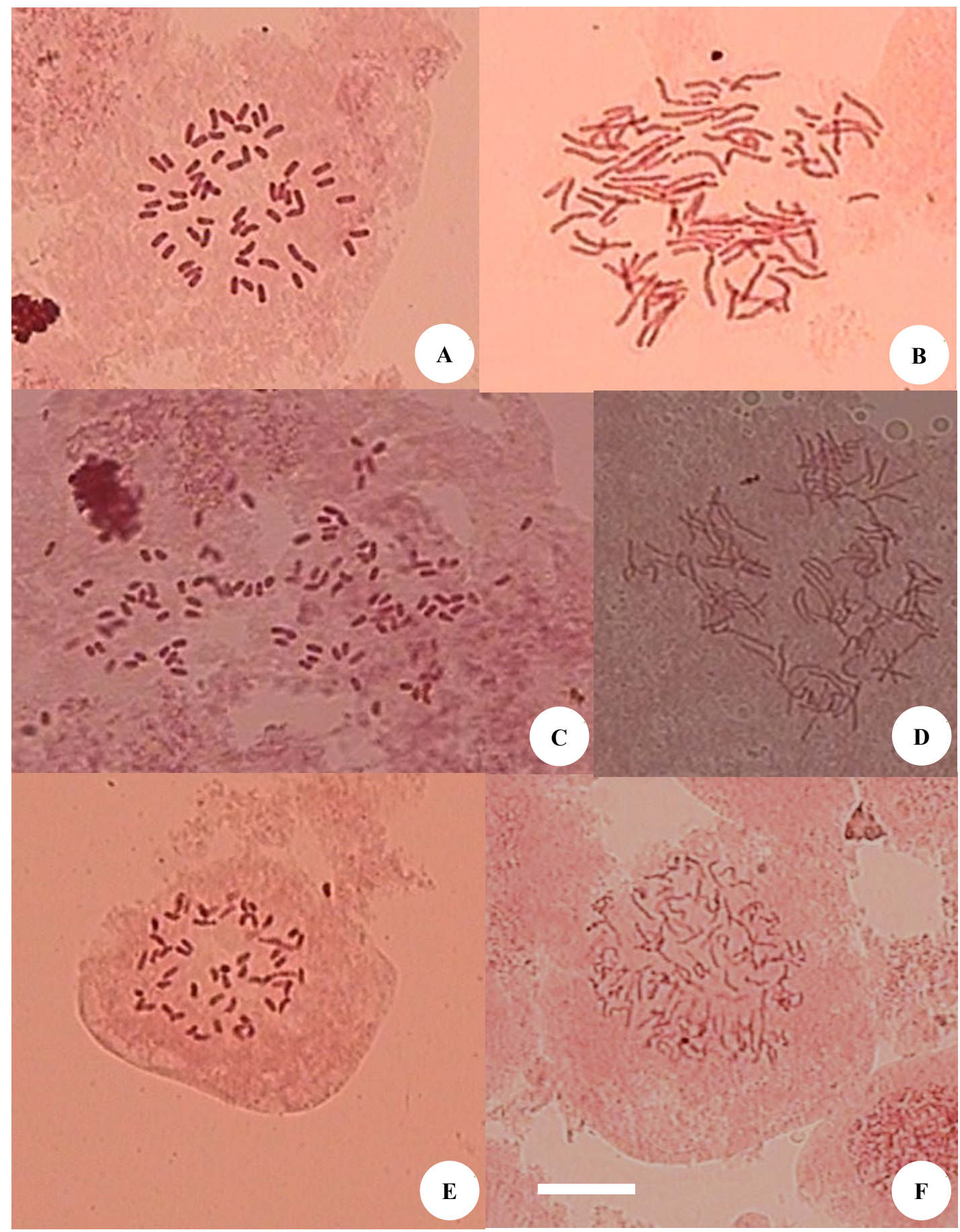




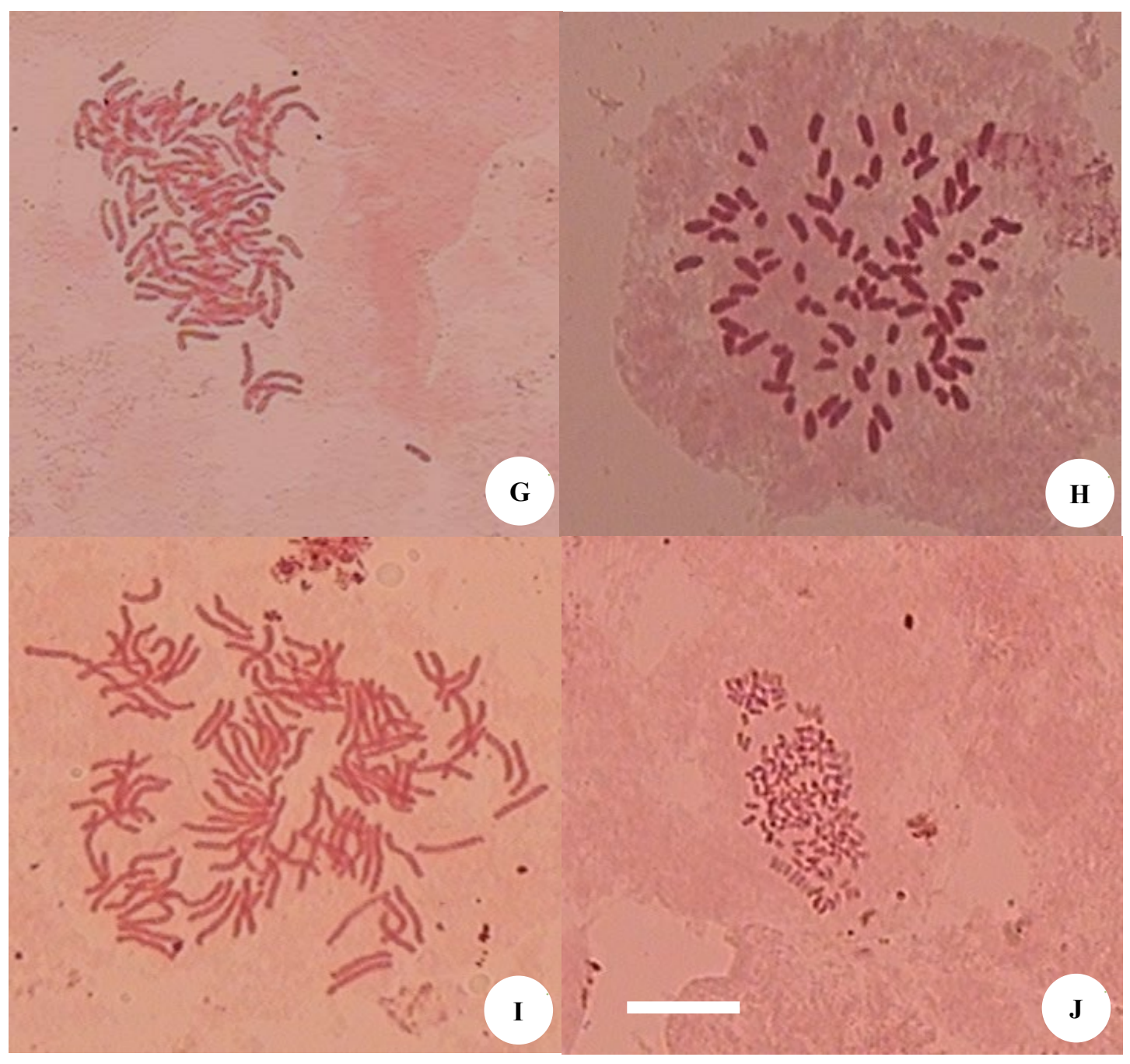

Figure 1. Somatic chromosome numbers of Pteris. A. Pteris biaurita $(\mathrm{TNgP} \& \mathrm{YF} 25,2 \mathrm{n}=58)$; B. Pteris fauriei $(\mathrm{MM} 156,2 \mathrm{n}=87)$; C. Pteris ensiformis var ensiformis (TNgP \& NI $08,2 \mathrm{n}=116)$; D. Pteris tripartita (MM 142, $2 \mathrm{n}=116)$; E. Pteris tripartita $(\mathrm{TNgP} \&$ YF 26, 2n = 58); F. Pteris multifida (MM 145, 2n =116); G. Pteris sp. (MM 185, 2n = 87); H. Pteris fauriei (TNgP \& NI, 2n = 87); I. Pteris longipinnula (MM 163, $2 \mathrm{n}=116)$; J. Pteris vittata $(\mathrm{TNgP} \&$ NI 02, $2 \mathrm{n}=116)$. Scale bar $=10 \mu \mathrm{m}$ for all.

As reviewed by Chao et al. (2012), the Chinese ladder brake $P$. vittata shows considerable morphological variations and wide geographical distribution throughout the world. Diverse ploidy levels and reproductive modes have been recorded, including sexual diploids, triploids, sexual and apogamous tetraploids, pentaploids, and hexaploids (Grant 1981; Walker 1962; Khare and Kaur 1983a; Wang 1989; Tsai and Shieh 1984; Roy et al. 1971; Kato et al 1992; Mitui 1976; Srivastava et al. 2007). The variability of the ploidy in $P$. vittata revealed that we are dealing with an apogamic species-complex (Brullo et al. 1982), as has already been verified in other species of this genus (Walker 1962; Verma and Khullar 1965). Among these polyploids, tetraploid is the most common whereas pentaploid and triploid are rare (Khare and Kaur 1982b). A similar situation was also reported from Java, pentaploid $P$. vittata were rarer among the most common cytotype, tetraploid type (Mumpuni et al. 2015).
Diploid type of $P$. vittata is also rare in the world. Sexual diploid was found in Yunnan, Southwestern China (Kato et al. 1992). Bronwlie (1965) reported $P$. vittata with chromosome number $\mathrm{n}=58$ from Kalabere, New Caledonia, but there was no information on its type reproduction of this record so that we do not recognize whether this record was apogamous diploid or sexual tetraploid. Cytological surveys on $P$. vittata conducted by Srivastava et al. (2007) in India indicated that at least four cytotypes, namely diploid, triploid, pentaploid and hexaploid, are threatened in their native habitats. The diploid type of $P$. vittata from the Malesian region has not been reported yet (Praptosuwiryo and Darnaedi 2008; Mumpuni et al. 2015). Therefore most of the cytotypes of $P$. vittata reported from many locations in the world were tetraploid.

In this study, $P$. vittata is found to be tetraploid sexual $(2 \mathrm{n}=116)$. This plant was collected from lowland areas, 
ca. 250-300 m asl. Cytological observation of $P$. vittata of Himalaya (Bowali, Kumaon, Nortwest Himalaya) which was growing at $1800 \mathrm{~m}$ asl. revealed sexual diploid $(2 \mathrm{n}=$ 58) (Punetha and Sen 1989). It is clearly proved that the ploidy level in $P$. vittata is not affected by altitude. Recently the cytological report on $P$. vittata in Java (Mumpuni et al. 2015 ) showed also that the ploidy level of this species was not affected by altitude. The tetraploid and pentaploid $P$. vittata were found in both lowland and mountainous area.

The cytological data of Pteris in Java has given an evident that Indonesia is one the centers speciation of Pteris in the world. Walker (1962) stressed that Pteris had many centers of speciation, mainly the West Indies and Central America, Madagascar, Indonesia, New Guinea, the Philippines, and the Sino-Japanese area. Table 1. also indicates several patterns of speciation on the fern genus Pteris in Java have been occurred, namely polyploidy and breeding structure. Of eight species of Pteris investigated from Java, seven species have polyploid types. The dynamic aspect of ploidal evolution was pointed out by Haufler (1987). Speciation is the formation of a species. Polyploidy is now widely recognized as one of the principal methods for the formation of new species among the higher plants (Stebbins 1950). Two breeding structure are occurred in Javan Pteris, namely sexual and apogamous.

In conclusions, all species of Pteris have basic chromosome number $\mathrm{x}=29$. Pteris biaurita is apogamous diploid $(2 \mathrm{n}=58)$. Pteris ensiformis var ensiformis shows the chromosome number of $2 \mathrm{n}=87$ (apogamous triploid) and $2 \mathrm{n}=116$ (sexual tetraploid), while $P$. ensiformis var. victoriae reveals $2 \mathrm{n}=58$ (sexual diploid). Pteris fauriei is apogamus triploid $(2 \mathrm{n}=87)$. Pteris longipinnula shows chromosome number $2 \mathrm{n}=116$ (tetraploid). Pteris multifida and $P$. vittata are sexual tetraploids $(2 \mathrm{n}=116)$. Pteris tripartita has two ploidy level, viz sexual diploid $(2 \mathrm{n}=58)$ and sexual tetraploid $(2 \mathrm{n}=116)$. Pteris sp. has $2 \mathrm{n}=87$ (apogamous triploid). Another currently unplaced Javanese Pteris sp. has $2 \mathrm{n}=87$ (apogamous triploid). New record cytotypes of Pteris for Central Java are reported, viz. diploid $P$. biaurita, tetraploid $P$. ensiformis, triploid $P$. fauriei, diploid $P$. tripartita and teraploid $P$. vittata. The cytological data of Pteris in Java has given an evident that Indonesia is one of the speciation centers of Pteris in the world. Discussing ploidy in the species of Pteris in relation to plant morphological variation across their geographical distribution revealed that Pteris has many centers of speciation in the world, notably the West Indies and Central America, Madagascar, Indonesia, New Guinea, the Philippines, and the Sino-Japanese area. The distribution pattern of different cytotypes in Pteris may indicate that the tropics is more favourable to the formation and surviving of polyploid than the subtropics.

\section{ACKNOWLEDGEMENTS}

We thank Muhamad Ridwan, Deni Hamdani and Kusnadi (Bogor Botanical Gardens) for assisting in collecting the living materials at surrounding Curug Nangka, Mt. Salak, West Java. Niko Islamika (Satya Wacana University, Sala Tiga, Central Java) assisted in sample collection in Mojosongo subdistrict, Boyolali district, and Bringin, Semarang district, Central Java. Asri Handini and Puji Nugroho (Boyolali) help us in collecting Pteris in Bringin, Semarang, Central Java. Yogi Febriyanto helped us in maintaining living materials in the greenhouse of Bogor Botanical Gardens. Teguh Hasto Priatmo (Bogor Botanical Gardens) made herbarium specimen vouchers of the materials studied. I would also like to thank Dr. Graham Eagleton (Australia) for giving critical comments, suggestion to improve this manuscript. I wish to thank the anonymous reviewers for their help and suggestions to improve this manuscript. Part of the field work for collecting the living collections was funded by Proyek Nasional No. 09, Pusat Konservasi Tumbuhan-Kebun Raya, LIPI, in the year 2011.

\section{REFERENCES}

Abraham A, Ninan CA, Mathew PM. 1962. Studies on the cytology and phylogeny of the pteridophytes: VII. Observation on one hundred species of south Indian ferns. J Indian Bot Soc 41: 339-421.

Backer CA, Posthumus O. 1939. Varenflora voor Java. Uitgave van's Lands Plantetuin, Buitenzorg.

Bir SS. 1988. Evolutionary trends in the pteridophytic flora of India. Presidential address, Section of Botany. 75th Indian Science Congress (Platinum Jubilee Session), 1-56. Indian Science Congress Association, Calcutta.

Brownlie G. 1965. Chromosome numbers in some Pacific Pteridophyta. Pac Sci 19: 493-497.

Brullo S, De Leonardis W, Pavone P. 1982. Chromosome numbers of some Sicilian ferns. 1. Webbia 35 (2): 275-281.

Chao Y-S, Ebihara A, Chiou W-L, Huang Y-M. 2017. Pteris latipinna sp. nov. (Pteridaceae), a new species segregated from Pteris fauriei. PhytoKeys 85: 95-108.

Chao Y-S, Yi-Han Chang Y-H, Ngan L-T, Truong D-V, Liu H-Y, Chiou W-L. 2012a. Different ploids of Pteris grevilleana Wall. ex Agardh var. ornata Alderw. (Pteridaceae) in Taiwan and Vietnam. Taiwania 57 (3): 278-282

Chao Y-S, Liu H-Y, Chiang Y-C, Chiou W-L. 2012b. Polyploidy and speciation in Pteris (Pteridaceae). J Bot. Article ID 817920, 7 pages; DOI: $10.1155 / 2012 / 817920$.

Chao Y-S, Rouhan G, Amoroso VB, Chiou W-L. 2014. Molecular phylogeny and biogeography of the fern genus Pteris (Pteridaceae). Ann Bot 114: 109-124.

Cubas P. 1989. Procesos citogenéticos de especiación en Pteridophyta. Anal Jard Bot Madrid 46: 519-531.

Copeland EB. 1947. Genera Filicum. Chronica Botanica, Waltham.

Darnaedi D. 1992. A preliminary cytological study of fern flora of GedePangrango National Park (West Java). Proc Sem Asian Pterid II: 7378.

Ebihara A, Nakato E, Matsumoto S, Chao Y-S, Kuo L-Y. 2014. Cytotaxonomic studies on thirteen ferns of Taiwan. Bull Natl Mus Nat Sci, Ser B, 40 (1): 19-28.

Edie HH. 1978. Ferns of Hongkong. Hongkong University Press, Hongkong.

Efendi M, Chikmawati T, Darnaedi D. 2014. New cytotypes of Pteris ensiformis var. victoriae from indonesia. Reinwardtia 14 (1): 133135.

Fabri F. 1963. Primo supplemento alle Tavole cromosomiche della Pteridophyta di Arberto Chiarugi. Caryologia 16: 237-335.

Fukui K. 1996. Plant chromosomes at mitosis. In: Fukui K, Nakayama S (Eds) Plant Chromosomes: Laboratory Methods. CRC Press, Boca Raton.

Grant V. 1981. Plant Speciation. Columbia University Press, New York. 
Hastuti DV, Praptosuwiryo TNg, Djuita NR. 2011. Sitologi dan tipe reproduksi Pteris multifida Poir. (Pteridaceae). Bul Kebun Raya Ind 14 (1): 8-18. [Indonesian]

Haufler CH. 1987. Electrophoresis is modifying our concepts of evolution in homosporous pteridophytes. Amer J Bot 74: 953-966

Holttum RE. 1954. A Revised Flora of Malaya. II. Ferns of Malaya. Government Printing Office, Singapore.

Holttum RE. 1966. A Revised Flora of Malaya. II. Ferns of Malaya Government Printing Office, Singapore.

Holttum RE, Roy SK. 1965. Cytological observations on ferns from New Guinea with descriptions of new species. Blumea 8 (1): 129-138.

Huang YM, Chou HM, Hsieh TH, Wang JC, Chiou WL. 2006. Cryptic characteristics distinguish diploid and triploid varieties of Pteris fauriei (Pteridaceae). Can J Bot 84: 261-268.

Huang Y-M, Chou H-M, Wang J-C, Chiou W-L. 2007. The distribution and habitats of the Pteris fauriei complex in Taiwan. Taiwania 52 (1) 49-58.

Ivanova D, Pie kos'-Mirkowa H. 2003. Chromosome numbers of Polish ferns. Acta Biol Cracov Ser Bot 45 (2): 93-99.

Jaruwattanaphan T, Matsumoto S, Watano Y: 2013. Reconstructing hybrid speciation events in the Pteris cretica group (Pteridaceae) in Japan and adjacent regions. Sys Bot 38 (1):15-27.

Kato M, Nakato N, Cheng X, Iwatsuki K. 1992. Cytotaxonomic study of ferns of Yunnan, Southwestern China. Bot Mag Tokyo 105: 105-124.

Khare PB, Kaur S. 1982. New Cytotypes of Pteris vittata L. From Lucknow; Abst. 69th Indian Sci. Congr., Mysore.

Khare P, Kaur S. 1983a. Gametophyte differentiation of pentaploid Pteris vittata L. Proc Indian Nat Sci Acad B49 No 6. 740-742.

Khare P, Kaur S. 1983b. Intraspecific polyploidy in Pteris vittata Linn. Cytologia 48 (1): 21-25.

Knobloch IW. 1966. A preliminary review of spore number and apogamy within the genus Cheilanthes. Amer Fern J 56: 163-167.

Lovis JD. 1977. Evolutionary patterns and processes in ferns. Adv Bot Res 4: 229-415.

Ma LQ, Komar KM, Tu C, Zhang WH, Cai Y, Kenneley ED. 2001. A fern that hyperaccumulates arsenic. Nature 409: 579.

Manton I. 1950. Problems of Cytology and Evolution in the Pteridophyta. Columbia University Press, New York.

Manton I, Sledge WA. 1954. Observations on the cytology and taxonomy of the Pteridophyte flora of Ceylon. Phil Trans Roy Soc London B. 238: $127-185$.

Martínez OG. 2011. Morfología y distribución del complejo Pteris cretica (Pteridaceae). Candollea 66: 159-180.

Martínez OG. 2016. Pteris sotae (Pteridaceae), a new endemic species for the Argentinean flora. Phytotaxa 267 (4): 291-295.

Mitui K. 1976. Chromosome numbers of some ferns in the Ryukyu Islands. J Jap Bot 51: 33-41.

Mitui K. 1980. Chromosome numbers of Japanese Pteridophytes. Bull Nipp Den Univ, Gen Educ 9: 215-229.

Mumpuni M, Chikmawati T, Praptosuwiryo TNg. 2015. Poliploidi intraspesifik Pteris vittata L. (Pteridaceae) di Pulau Jawa. Floribunda 5 (2): 53-59. [Indonesian]

Nakato N, Ebihara. 2016. Chromosome numbers of 18 ferns in Japan: Toward completion of chromosome information in Japanese ferns. Bull Natl Mus Nat Sci, Ser B 42 (1): 25-40.

Peruzzi L, Góralski G, Joachimiak AJ, Bedini G. 2012. Does actually mean chromosome number increase with latitude in vascular plants? An answer from the comparison of Italian, Slovak and Polish floras. Compar Cytogen 6 (4): 371-377.

Prado J, Windisch PG. 2000. The genus Pteris L. (Pteridaceae) in Brazil Bolet Institu Botán, São Paulo 13: 103-199.
Praptosuwiryo TNg. 2003. Studi kromosom somatik beberapa jenis tumbuhan paku di Pulau Lombok dan Sumbawa. Widyariset 5: 87-96.

Praptosuwiryo TNg. 2013. The rare Pteridophytes of Mt. Slamet with three species new records for Java. Floribunda 4 (6):138-146.

Praptosuwiryo TNg, Darnaedi D. 2008. Cytological observation on fern genus Pteris in the Bogor Botanic Gardens. Bul Kebun Raya Indo. 11 (2): $15-23$.

Punetha N, Sen A. 1989. Cytological observations on some species of Pteris L. from Kumaon (northwest Himalaya). Proc Indian Acad Sci (Plant Sci.) 99 (2): 131-134.

Roy SK, Holttum RE. 1965. Cytological observations on ferns from Southern China. Amer Fern J 55 (4):154-164

Roy RP, Sinha BMB, Sakya AR. 1971. Cytology of some ferns of Kathmandu valley. Fern Gazette 10: 193-199.

Schneider H, Rusea G. 2013. Pteris L. In: Winter WP, Amoroso VB (eds), Plant Resources of South-East Asia. Cryptogams fern and fern allies. PROSEA 15 (2). Backhuys, Leiden.

Shieh W-C. 1975. Pteridaceae. In: Li H-L. et al. (eds) Flora of Taiwan, 1st ed. 1. Epoch, Taipei.

Shieh W-C. 1994. Pteridaceae. In: Huang T-C. et al. (eds) Flora of Taiwan, 2nd ed. 1. Department of Botany, National Taiwan University, Taipei.

Stebbins GL. 1950. Variation and Evolution in Plants. Columbia University Press, New York.

Srivastava J, Ranade SA, Khare PB. 2007. Distribution and threat status of the cytotypes of Pteris vittata L. (Pteridaceae) species complex in India. Curr Sci 93 (1): 81-85.

Tryon RM, Tryon AF. 1982. Pteris. In: RM Tryon, AF Tryon (eds.). Ferns and Allied Plants: With Special Reference to Tropical America. Springer-Verlag New York Inc., New York.

Tryon RM, Tryon AF, Kramer KU. 1990. Pteridaceae. In: Kramer KU, Green PS (eds). Pteridophytes and Gymnosperms. In: Kubitski K. (ed) The Families and Genera of Vascular Plants 1, Springer Verlag, Berlin.

Tsai J-L, Shieh W-C. 1984. A cytotaxonomic survey of the pteridophytes in Taiwan (2) chromosome and spore characteristics. J Science \& Engin 21: 57-70.

Verma SC, Khullar SP. 1965. Cytology of some W. Himalayan Adiantaceae (sensu Alston) with cytotaxonomic comments. Caryologia 18: 85-106.

Wang ZR. 1989. A preliminary study on cytology of Chinese Pteris. Acta Phytotax Sin 27 (6): 421-438.

Walker TG. 1962. Cytology and evolution in the fern genus Pteris L. Evolution 16 (1): 17-43.

Walker TG. 1966. IX.-A cytotaxonomic survey of the Pteridophytes of Jamaica. Trans Roy Soc Edin 66 (9): 169-245.

Walker TG. 1979. The cytogenetics of ferns. In AF Dyer (ed) The Experimental Biology of Ferns. Academic Press, London.

Walker TG. 1984. Chromosomes and evolution in pteridophytes. In: Sharma AK, Sharma A (eds.). Chromosomes in Evolution of Eukaryotic Groups 2. CRC Press, Boca Raton.

Wagner WH Jr. 1954. Reticulate evolution in Appalachian Asplenium. Evolution 8: 103-118.

Wang ZR. 1989. A preliminary study on cytology of Chinese Pteris. Acta Phytotax Sin 27 (6): 421-438.

Windham MD, Yatskievych G. 2003. Chromosome studies of cheilanthoid ferns (Pteridaceae: Cheilanthoideae) from the Western United States and Mexico. Amer J Bot 90 (12): 1788-1800.

Zubaidah S. 1998. Kajian sitologi, tipe reproduksi dan ciri-ciri morfologi Pteris biaurita L. di daerah berketinggian berbeda [Tesis]. Malang: Program Studi Biologi, Program Pasca Sarjana, IKIP Malang. [Indonesian] 